\title{
Prediksi Senyawa Aktif Pada Tanaman Obat Berdasarkan Kemiripan Struktur Kimiawi untuk Penyakit Diabetes Tipe II
}

Penulis

Afiliasi

\author{
Rizal Bakri ${ }^{{ }^{*}}$, Hari Wijayanto ${ }^{2}$, Farit Mochamad Afendi ${ }^{2}$ \\ ${ }^{1}$ Program Studi Statistika, FMIPA, Universitas Negeri Makassar \\ ${ }^{2}$ Departemen Statistika, FMIPA, Institut Pertanian Bogor, Indonesia.
}

\section{Kata Kunci \\ $\rightarrow$ Diabetes Tipe II \\ - Jamu \\ - Modifikasi Tanimoto \\ ○ Sidik jari molekuler}

Diterima 26 Agustus 2015 Direvisi 23 Agustus 2016 Disetujui 9 November 2016

*Penulis korespondensi Rizal Bakri

Program Studi Statistika, FMIPA, Universitas Negeri Makassar Jl. Daeng Tata Raya, Makassar, Indonesia

Email: rizal.bakri@unm.ac.id

\section{ABSTRAK}

Diabetes melitus merupakan penyakit metabolik yang dicirikan oleh tingginya kadar glukosa dalam darah. Di Indonesia jumlah penderita diabetes menempati urutan keempat di dunia setelah Amerika Serikat, India, dan Cina dengan jumlah penderita mencapai lebih dari 12 juta jiwa. Salah satu upaya yang dilakukan untuk mengatasi diabetes adalah mengkonsumsi obat herbal berupa jamu sebagai alternatif obat sintetik. Pusat Studi Biofarmaka Bogor sedang mengembangkan ramuan jamu untuk penyakit Diabetes Melitus Tipe II yang terdiri dari empat tanaman obat yaitu pare (Momordica charantia), sembung (Blumea balsamifera), bratawali (Tinospora crispa), dan jahe (Zingiber officinale). Kandungan senyawa keempat tanaman diduga memiliki aktivitas biologis yang mirip dengan senyawa sintetik. Pada prinsipnya, diasumsikan bahwa senyawa yang struktur kimiawinya mirip memiliki sifat biologis yang mirip. Kemiripan senyawa diukur menggunakan koefisien Modifikasi Tanimoto dengan sidik jari molekuler KR. Hasil penelitian menunjukkan bahwa tanaman Bratawali merupakan tanaman utama pada ramuan jamu untuk penyakit diabetes berdasarkan jumlah kandungan senyawa yang dominan mirip dengan senyawa sintetik yaitu senyawa $N$-trans-feruloyltyramine (B015) dan $\mathrm{N}$-formylanonaine (B018). Selanjutnya, Senyawa-senyawa yang memiliki nilai kemiripan tinggi dengan senyawa sintetik diperoleh pula pada senyawa karaviloside I (P195) dari tanaman pare, senyawa xanthoxylin (S002) dari tanaman sembung, senyawa borneol (J207) dan (-)- isoborneol (J226) dari tanaman Jahe.

\section{PENDAHULUAN}

Diabetes melitus merupakan penyakit metabolik yang dicirikan oleh tingginya kadar glukosa dalam darah. Penyakit ini adalah salah satu penyakit kondisi kronis yang dapat diderita seumur hidup dan memiliki komplikasi (menyebabkan terjadinya penyakit lain). Hal ini berkaitan dengan kadar gula darah yang tinggi secara terus menerus, sehingga berakibat pada rusaknya pembuluh darah, saraf, dan struktur internal lainnya (Sari 2010). Badan Kesehatan Dunia, WHO (World Health Organization) menyebutkan bahwa pada tahun 2003 tercatat jumlah penderita diabetes berusia 20-79 tahun dari 
3.8 milyar penduduk dunia adalah sebesar 194 juta jiwa dan diperkirakan jumlahnya akan meningkat menjadi 333 juta jiwa pada tahun 2025. Sementara itu, di Indonesia jumlah penderita diabetes menempati urutan keempat di dunia setelah Amerika Serikat, India, dan Cina dengan jumlah penderita mencapai lebih dari 12 juta jiwa (Depkes 2014).

Upaya yang dilakukan untuk mengatasi diabetes adalah mengonsumsi obat herbal berupa jamu sebagai alternatif obat sintetik. Indonesia memiliki kekayaan tanaman obat dan ramuan jamu dari berbagai suku yang tersebar di berbagai wilayah Indonesia. Riset kesehatan dasar (Riskesdas) tahun 2010, menunjukkan bahwa $49.53 \%$ penduduk Indonesia menggunakan jamu baik untuk menjaga kesehatan maupun untuk pengobatan karena sakit (Siswanto 2012). Sementara, Nurishmaya (2014) berdasarkan ramuan jamu yang sedang dikembangkan di Pusat Studi Biofarmaka Bogor, terdapat empat tanaman obat yang berkhasiat mengobati penyakit Diabetes Melitus Tipe II yaitu pare (Momordica charantia), sembung (Blumea balsamifera), bratawali (Tinospora crispa), dan jahe (Zingiber officinale).

Kandungan senyawa yang terdapat pada keempat tanaman tersebut diduga memiliki aktivitas biologis yang mirip dengan senyawa sintetik. Pada prinsipnya diasumsikan senyawa yang struktur kimiawinya mirip memiliki sifat biologis yang mirip (Johnson \& Maggiora 1990). Koefisien kemiripan Tanimoto merupakan koefisien yang sering digunakan untuk mengukur kemiripan struktur kimiawi suatu senyawa. Sementara Fligner et al. (2014) telah menemukan koefisien baru yang merupakan modifikasi dari koefisien Tanimoto dan memiliki tingkat akurasi yang lebih tinggi. Suatu pasangan senyawa dikatakan mirip apabila memiliki jumlah fitur yang sama dan pasangan senyawa dikatakan tidak mirip apabila fiturfiturnya berbeda. Sementara, Klekota \& Roth (2008) telah mengumpulkan 4860 fitur sidik jari molekuler unik yang merupakan substruktur berbagai senyawa melalui berbagai jenis teknik fragmentasi.

Penelitian ini bertujuan untuk memprediksi senyawa aktif pada keempat tanaman obat dengan melihat kemiripan struktur kimiawi dengan obat sintetik antidiabetes yang telah disetujui oleh Food and Drug Administration (FDA).

\section{METODE}

Data

Data yang digunakan dalam penelitian ini adalah struktur kimiawi senyawa berasal dari jamu yang terdiri atas 4 tanaman yaitu Bratawali (Tinospora crispa), Jahe (Zingiber officinale), Pare (Momordica charantina), Sembung (Blumea balsamifera) yang sedang dikembangkan di Pusat Studi Biofarmaka Institut Pertanian Bogor (PSB-IPB) untuk penyakit diabetes tipe 2. Senyawa dari 4 tanaman tersebut diperoleh di Take Out "Jamu" of Knapsack database (http://kanaya.naist.jp/knapsack_jsp/top.html) dan The Dictionary of Natural Products (DNP) databases (http://dnp.chemnetbase.com/) dengan kata kunci nama latin tanaman (Afendi et al. 2012; Running 1993). Jumlah senyawa yang diperoleh dari kedua database adalah 595 senyawa yang terdiri dari 291 senyawa jahe, 18 senyawa bratawali, 41 senyawa sembung, dan 245 senyawa pare. Adapun data mengenai obat kimia antidiabetes didapat dari database DrugBank http://www.drugbank.ca/ yaitu sebanyak 19 senyawa yang telah disetujui oleh FDA. Dari total 595 senyawa tanaman, terdapat 288 senyawa unik yang memiliki informasi yang lengkap. Adapun senyawa tanaman yang memiliki koneksi dengan protein target sejumlah 55 senyawa dari berbagai pencarian database. Struktur kimiawi berupa Simplified Molecular Input Line Entry System (SMILES) setiap senyawa tersebut dicari melalui situs NCBI database (https://pubchem.ncbi.nlm.nih.gov/) (Wang et al. 2009).

\section{Metode Analisis}

Mengubah struktur kimiawi setiap senyawa berupa SMILES menjadi data biner menggunakan sidik jari molekuler Klekota\&Roth ( $K R$ fingerprint) dengan 4860 fitur. Pada langkah ini digunakan aplikasi R dengan paket $R C D K$ dan fingerprint.

Mencari informasi fitur setiap pasangan senyawa dan dapat diekpresikan ke dalam tabel kontingensi berukuran $2 \times 2$ (Tabel 1). Informasi fitur ini akan digunakan dalam perhitugan kemiripan pasangan suatu senyawa menggunakan formula koefisien Modifikasi Tanimoto. 
Tabel 1. Tabel kontingensi Data Biner

\begin{tabular}{rcccc} 
& \multicolumn{5}{c}{ Senyawa ke- $i^{-1}$} & Total \\
Senyawa ke- $i^{b}$ & 1 & 1 & 0 & $a+b$ \\
& 0 & $a$ & $b$ & $c+d$ \\
\hline Total & $c$ & $a+c$ & $b+d$ & $n=a+b+c+d$ \\
\hline
\end{tabular}

Dengan:

$a \quad=$ frekuensi kedua senyawa bernilai 1

$b, c \quad=$ frekuensi satu fitur bernilai 1 dan fitur lainnnya bernilai 0

$d=$ frekuensi kedua senyawa bernilai 0

$n \quad=$ total jumlah fitur.

Menghitung kemiripan struktur kimiawi pasangan senyawa dengan koefisien biner Modifikasi Tanimoto (Fligner et al. 2014). Koefisien ini merupakan modifikasi dari koefisien Tanimoto dengan memperhatikan fitur-fitur suatu fingerprint yang tidak terdapat pada pasangan senyawa $(d)$ dengan formula sebagai berikut:

$M T=\left(\frac{2-\hat{p}}{3}\right) T_{1}+\left(\frac{1+\hat{p}}{3}\right) T_{0}$

dengan $\hat{p}=\frac{(n-d)+a}{2 n}, T_{1}=\frac{a}{n-d}$, dan $T_{0}=\frac{d}{n-a}$.

Membuat plot kemiripan struktur kimiawi bahan aktif tanaman obat dengan struktur obat sintetik antidiabetes menggunakan heatmap di R. Plot ini akan memberikan gambaran mengenai ukuran kemiripan struktur kimia suatu senyawa yang akan menjadi pemilihan kandidat senyawa dalam tanaman.

\section{HASIL DAN PEMBAHASAN}

\section{Konstruksi strukur kimiawi senyawa}

Langkah awal dalam penelitian ini adalah menentukan senyawa aktif yang memiliki aktivitas secara biologis yaitu dengan melihat protein targetnya. Senyawa yang memiliki protein target diduga berinteraksi dengan protein-protein dalam tubuh. Pada penelitian ini jumlah senyawa yang memiliki protein target sebanyak 55 dari total 595 senyawa. Senyawasenyawa yang memiliki protein target ditentukan kemiripannya dengan senyawa pada obat sintetik antidiabetes karena penelitian ini berlandaskan pada prinsip bahwa senyawa yang struktur kimiawinya mirip maka memiliki sifat biologis yang mirip. Total senyawa yang digunakan sebanyak 79 senyawa yang terdiri dari 55 senyawa aktif tanaman obat dan 19 senyawa sintetik dengan jumlah pasangan senyawa berbeda antara senyawa aktif tanaman obat dan sintetik sebanyak 1045. Senyawa-senyawa yang berbentuk SMILES telah diubah menjadi beberapa substruktur berdasarkan fitur-fitur sidik jari molekuler. Pada penelitian ini sidik jari molekuler yang digunakan adalah sidik jari molekuler yang telah dikembangkan oleh Klekota dan Roth (KR fingerprint) dengan 4860 fitur. Pemilihan sidik jari molekuler ini berlandaskan pada jumlah fitur yang dimilikinya lebih banyak daripada jenis sidik jari molekuler lain seperti MACCS, Estate, Pubchem, dan lain-lain. Pada proses sidik jari molekuler suatu senyawa, senyawa yang memiliki substruktur yang sama dari 4860 fitur disimbolkan dengan 1 sedangkan fitur lain disimbolkan 0 . Sehingga, struktur data yang terbentuk berupa matriks dengan ukuran 79x4860 yang berisi kumpulan data biner.

\section{Kemiripan senyawa aktif tanaman obat dan sintetik}

Kemiripan struktur kimia suatu senyawa telah dihitung menggunakan koefisien Modifikasi Tanimoto dengan rentang nilai kemiripan yang dihasilkan adalah 0 sampai 1 . Pasangan senyawa memiliki nilai kemiripan tinggi apabila hasil dari koefisien Modifikasi Tanimoto mendekati 1 . Kemiripan senyawa aktif pada tanaman obat dengan senyawa obat sintetik antidiabetes memiliki nilai kemiripan yang bervariasi seperti yang tersaji pada Gambar 1. Pada Gambar 1 menunjukkan 
bahwa skala horizontal merupakan senyawa sintetik antidiabetes sedangkan skala vertikal merupakan senyawa aktif dari 4 tanaman obat. Gambar 1 menjelaskan bahwa terdapat 11 dari 19 senyawa sintetik memiliki kemiripan struktur dengan senyawa tanaman obat. Pemilihan senyawa kandidat berdasarkan batas ukuran kemiripan minimum yang telah ditetapkan. Pada penelitian ini, batas minimum ukuran kemiripan yang ditetapkan adalah 0.5 sehingga pasangan-pasangan senyawa yang memiliki ukuran kemiripan lebih dari 0.5 akan diduga sebagai senyawa kandidat untuk mengobati penyakit diabetes. Umumnya, semakin tinggi nilai batas minimum yang ditetapkan maka semakin akurat kemiripan suatu pasangan senyawa. Senyawa sintetik dominan memiliki nilai kemiripan tinggi yaitu diatas 0.5 adalah acarbose (DB09) dan voglibose (DB10). Sementara, senyawa sintetik yang memiliki nilai kemiripan yang paling rendah dengan senyawa tanman obat yaitu metformin (DB07). Tanaman obat yang memiliki nilai kemiripan struktur kimia yang banyak dengan senyawa sintetik adalah tanaman bratawali yaitu senyawa $\mathrm{N}$-transferuloyltyramine (B015) memiliki nilai kemiripan diatas
0.5 dengan senyawa sintetik glimepiride (DB05), pioglitazone (DB12), rosiglitazone (DB13), dan repaglinide (DB14) sedangkan senyawa $\mathrm{N}$ formylanonaine (B018) memiliki nilai kemiripan diatas 0.5 dengan senyawa sintetik Gliquidone (DB04), pioglitazone (DB12), rosiglitazone (DB13), repaglinide (DB14), alrestatin (DB17), dan sitagliptin (DB18). Berdasarkan penelitian ini maka dapat diduga bahwa tanaman bratawali merupakan tanaman utama dalam ramuan jamu. Sementara, tanaman sembung hanya memiliki satu senyawa yang mirip dengan senyawa sintetik diatas 0.5 yaitu senyawa xanthoxylin (S002) dengan voglibose (DB10) sedangkan tanaman pare memiliki dua senyawa yang mirip dengan senyawa sintetik diatas 0.5 yaitu karaviloside I (P195) dan 5,19epoxycucurbita-6,23-diene-3,25-diol; (36,56,23E)-form (P044) dengan acarbose (DB09) dan voglibose (DB10). Di sisi lain, tanaman jahe dengan kandungan senyawa aktif yang banyak hanya memiliki nilai kemiripan diatas 0.5 dengan senyawa sintetik tertentu yaitu dominan mirip pada senyawa sintetik acarbose (DB09) dan voglibose (DB10).

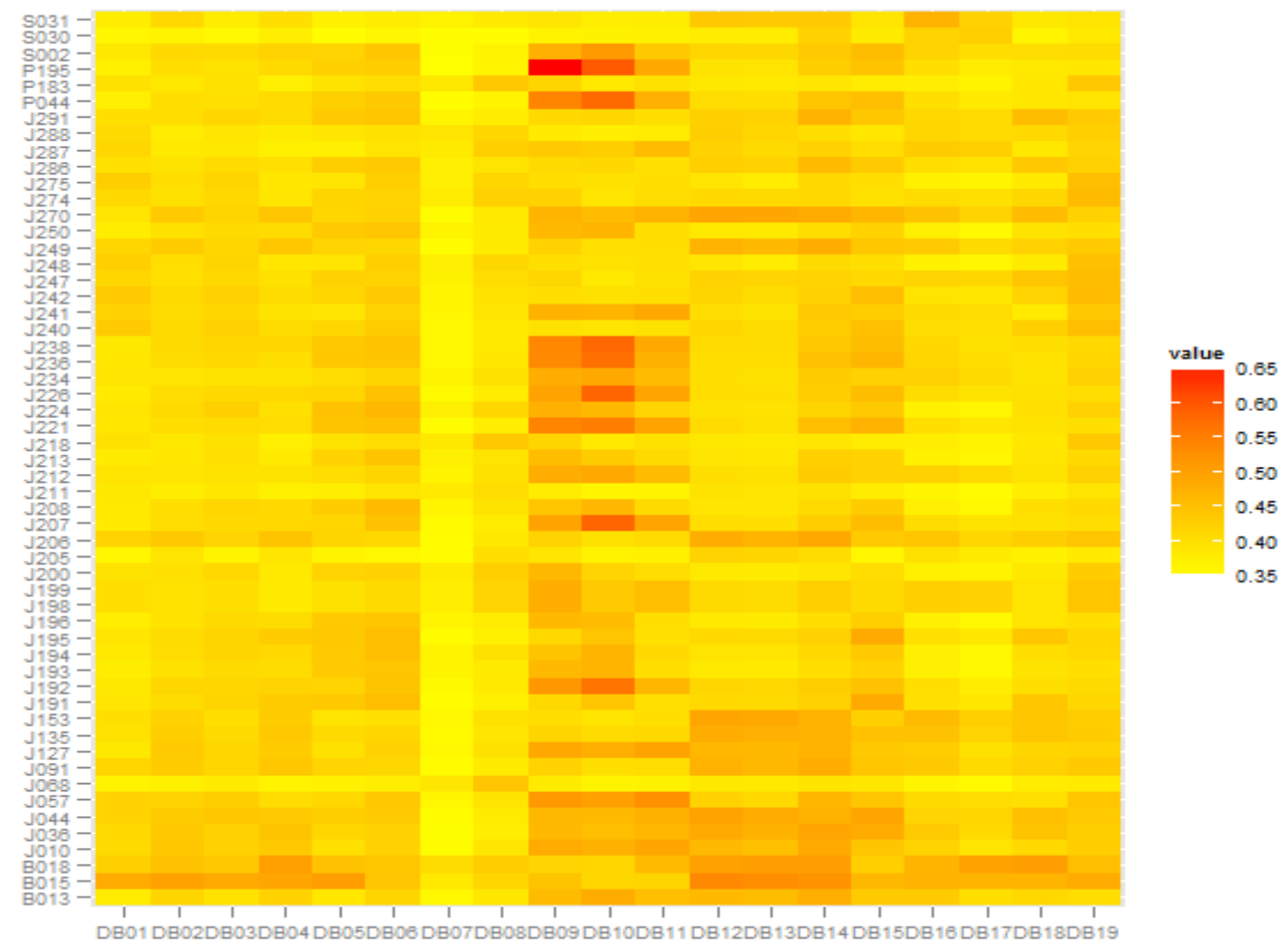

Gambar 1. Heatmap kemiripan struktur kimiawi senyawa 


\section{KESIMPULAN}

Penelitan ini berlandaskan pada prinsip bahwa senyawa yang struktur kimianya mirip memiliki fungsi biologis yang mirip. Pada studi in silico ini koefisien kemiripan yang digunakan adalah koefisien Modifikasi Tanimoto dengan sidik jari molekuler KR. Dari hasil penelitian diduga bahwa tanaman bratawali merupakan tanaman utama pada ramuan jamu untuk penyakit diabetes berdasarkan jumlah kandungan senyawa yang dominan mirip dengan senyawa sintetik yaitu senyawa $\mathrm{N}$-trans-feruloyltyramine (B015) dan $\mathrm{N}$ formylanonaine (B018). Senyawa-senyawa yang memiliki nilai kemiripan tinggi diperoleh pula pada senyawa karaviloside I (P195) dari tanaman pare, senyawa xanthoxylin (S002) dari tanaman sembung, senyawa borneol (J207) dan (-)- isoborneol (J226) dari tanaman jahe.

\section{DAFTAR PUSTAKA}

Afendi FM, Okada T, Yamazaki M, Hirai-Morita A, Nakamura Y, Nakamura K, Ikeda S, Takahashi H, Altaf-UI-Amin M, Darusman LK, Saito K, Kanaya S. 2012. KNApSAcK Family databases: Integrated metabolite-plant species databases for multifaceted plant research. Plant and Cell Physiology. 53(2):1-12.

[Depkes]. Departemen Kesehatan. 2005. Jumlah penderita diabetes Indonesia ranking-4 di dunia. [terhubung berkala]. http://www.depkes.go.id/download.php?file=d ownload/pusdatin/infodatin/infodatindiabetes.pdf. [10 Agustus 2015].

Fligner MA, Verducci JS, Blower PE. 2002. A Modification of the Jaccard-Tanimoto Similarity
Index for Diverse Selection of Chemical Compounds Using Binary Strings. Technometrics. 44(2):110-119.

Johnson AM, Maggiora GM. 1990. Concepts and Applications of Molecular Similarity. New York: John Willey \& Sons.

Klekota J, Roth FP. 2008. Chemical Substructures that Enrich for Biological Activity. Oxford Journal, Bioinformatics. 24(21):2518-25.

Nurishmaya MR. 2014. Pendekatan bioinformatika formulasi jamu baru berkhasiat antidiabetes dengan ikan zebra (Danio rerio) sebagai hewan model [skripsi]. Bogor (ID): Departemen Kimia, Fakultas Matematika dan Ilmu Pengetahuan Alam, Institut Pertanian Bogor.

Running WE. 1993. Chapman and Hall dictionary of natural products on CD-ROM. Journal of Chemical Information and Computer Sciences. 33:934-935.

Sari N. 2010. Potensi buah makasar (Brucea javanica (L.) Merr) sebagai inhibitor enzim $\alpha$-glukosidase [skripsi]. Bogor (ID): Departemen Biokimia, Fakultas Matematika dan Ilmu Pengetahuan Alam, Institut Pertanian Bogor.

Siswanto. 2012. Saintifikasi jamu sebagai upaya terobosan untuk mendapatkan bukti ilmiah tentang manfaat dan keamanan jamu. Buletin Penelitian Sistem Kesehatan. 15(2):203-211.

Wang Y, Xiao J, Suzek TO, Zhang J, Wang J, Bryant SH. 2009. PubChem: a public information system for analyzing bioactivities of small molecules. Nucleic Acids Research. 2(8):1-11. 